\title{
Mãos de cimento: as representações da Guerra do Contestado no imaginário de Irani, Santa Catarina
}

\author{
Ana Paula Motta ${ }^{1}$
}

\begin{abstract}
RESUMO: 0 artigo busca analisar as representações sociais sobre o Contestado no município de Irani, Santa Catarina, a partir da obra do folclorista, músico e pesquisador Vicente Telles. Tais representações foram interpretadas no contexto da gestão oficial da memória do Contestado, durante os dois mandatos do governador Esperidião Amin. 0 objetivo é apresentar uma reflexão sobre a influência das imagens mais "individuais" de Telles - desprovidas das narrativas pré-conceituais, acerca do movimento sertanejo, da guerra e da cultura cabocla, elaboradas pela imprensa, pela Igreja, pelos relatos militares na época da guerra e até mesmo por parte da historiografia - e as representações coletivas no município de Irani.
\end{abstract}

Palavras-chave: representações, políticas de memória, identidade, idealização, catecismo cívico, catarinismo.

\section{Cement hands: representations of the Contestant War in the imaginary of Irani, Santa Catarina}

\begin{abstract}
The paper analyzes the social representations about the Contestado in the municipality of Irani, Santa Catarina, based on the work of the folklorist, musician and researcher Vicente Telles. These representations were interpreted in the context of the official management of the Respondent's memory during the two terms of governor Esperidião Amin. The objective is to present a reflection on the influence of Telles' more "individual" images - devoid of preconceptual narratives, about the sertanejo movement, war and cabocla culture, elaborated by the press, the Church, military accounts at the time War and even by historiography - and the collective representations in the municipality of Irani.
\end{abstract}

Keywords: representations, memory politics, identity, idealization, civic catechism, catarinismo.

- Enviado em 01/10/2016

- Aprovado em 18/11/2016

\footnotetext{
${ }^{1}$ Bacharelado e Licenciatura em História- Universidade Federal do Paraná (UFPR). Especialização em História e Geografia o Paraná - Faculdades Bagozzi. Email: paulafmotta@yahoo.com.br
} 


\section{INTRODUÇÃo}

O artigo não tem por objetivo analisar o movimento ou a guerra. $\mathbf{O}$ texto não se refere à guerra propriamente dita, mas sim, às representações sociais que o episódio conhecido como Combate do Irani $^{2}$ é capaz de suscitar ainda hoje, passados pouco mais de cem anos, num espaço geográfico específico, ou seja, o município de Irani, localizado no Centro-Oeste de Santa Catarina.

Entendemos por representações o conjunto de imagens, ideias, crenças, concepções, visões de mundo, elaboradas socialmente e compartilhadas coletivamente por atores sociais que fazem uma determinada leitura do que concebem como realidade (WAGNER, 1998). Enquanto percepções do social, as representações não são, de forma alguma, discursos neutros. Emergem de interesses específicos, orientam as relações sociais, modelam comportamentos, práticas sociais e políticas, podendo justificar para os próprios indivíduos as suas escolhas e condutas (CHARTIER, 1990).

Tais representações podem compor o imaginário social acerca da guerra e do movimento, uma vez que fundamentam a criação de símbolos e mitos, e, ao mesmo tempo, são constituídas por eles. Mitos e símbolos são elementos imprescindíveis para se entender os valores sociais e políticos de determinados indivíduos, grupos, comunidades, sociedades ou culturas.

Escolhemos Irani por dois motivos. Primeiro, em função de sua sede urbana ser significativa em termos de monumentos, marcos ou referências alusivos a fatos de fundamental importância para a gestação do movimento social e dos rumos trilhados por ele. Além do Cemitério do Contestado, que já existia antes do Combate do Irani, da "sepultura" do monge e da escultura "Mãos de Cimento", símbolo do Contestado, também podemos encontrar na cidade o Museu do Contestado, cujo acervo é formado basicamente por fotografias de reconstituições cênicas referentes a episódios da guerra.

Segundo, em decorrência das atividades culturais, realizadas pelo músico, compositor, folclorista e pesquisador, Vicente Telles, relativas a temáticas do movimento, da guerra e da cultura sertaneja. Telles, morador de Irani, é autor de uma obra vasta e diversificada, a qual

\footnotetext{
${ }^{2} \mathrm{Na}$ época, pertencentes a Palmas, os Campos do Irani foram cenário do primeiro combate entre os seguidores de José Maria e parte do Regimento de Segurança do Paraná. Neste episódio, considerado, segundo muitos, o verdadeiro início da guerra, morreram as duas lideranças, respectivamente: o monge e comandante João Gualberto.
} 
desde o final da década de 1970 vem sendo capaz de envolver vários profissionais da produção científica e da área artística, e, ao mesmo tempo mobilizar a atenção de boa parte dos habitantes de Irani e de moradores de outros municípios do Estado. Estes têm prestigiado as produções de Telles, participando dos eventos que ele organiza, na forma de expectadores, ou ainda, interagindo como figurantes e atores dos desfiles e quadros cênicos realizados e concebidos pelo pesquisador.

Acreditamos que o processo de elaboração e reelaboração das imagens e das representações acerca da guerra passa pela dinâmica dos trabalhos desenvolvidos pelo folclorista. Vicente Telles também foi um dos mentores e idealizadores da construção de dois dos monumentos, e ainda atua na preservação e manutenção do conjunto, que integra o chamado Sítio Histórico do Contestado. Nesse sentido, uma análise das ideias, concepções e visões do referido autor - na medida em que as mesmas possam influenciar pensamentos e comportamentos coletivos em relação ao objeto social pode ser um procedimento eficaz para se interpretar e compreender as representações sociais ${ }^{3}$.

Procuramos pensar tanto a preservação dos monumentos quanto as produções e realizações de Telles, ricas em material simbólico, num contexto maior, ou seja, o do processo de construção de uma identidade para o homem catarinense, ao nosso ver, um dos elementos que nortearam políticas culturais de memória, acerca do Contestado, durante os dois mandatos do ex-governador Espiridião Amin. ${ }^{4}$

\footnotetext{
3 Encontramos Vicente em três ocasiões, todas no ano de 2006, quando ele tinha 75 anos. A primeira no mês de julho, durante pesquisa de campo, quando passamos uma semana em Irani, realizamos as entrevistas, acompanhamos o trabalho de Telles junto a duas escolas de outros municípios e conhecemos todos os monumentos. 0 segundo encontro foi em Curitiba, no dia 26 de julho, quando o folclorista fez uma apresentação musical no Museu Paranaense por ocasião da abertura da exposição Guerra do Contestado: 90 anos depois, a convite do Professor Doutor Nilson César Fraga, geógrafo que orientou nossa pesquisa, e, foi o idealizador dos eventos que marcaram as rememorações da guerra na capital do Paraná. E por último, em setembro de 2006, em Calmon município de Santa Catarina onde assistimos Vicente pela terceira vez. Em três turnos, mais de 1.000 pessoas assistiram na FECUCAL (Feira Cultural de Calmon) Telles tocar gaita e falar sobre o Contestado.
}

${ }^{4}$ Esperidião Amin foi governador do Estado de Santa Catarina por duas vezes: a primeira de 1883 a 1987 e a segunda de 1999 a 2002. 


\section{DE FACÍNORAS, IGNORANTES E FANÁTICOS A HERÓIS: ECOS DO CONTESTADO EM SANTA CATARINA}

Heróis são símbolos poderosos, encarnações de ideias e aspirações, pontos de referência, fulcros de identificação coletiva. (José Murilo de Carvalho. A Formação das Almas)

Uma viagem pelos municípios que integram o Planalto Norte e Centro-Oeste de Santa Catarina ainda abre possibilidades para um diálogo com o passado. Fragmentos da época do Contestado, como: cemitérios, crematórios, grutas, nascentes ou olhos d'água de São João Maria, construções da Brazil Lumber; ${ }^{5}$ túneis, trilhos e estações ferroviárias, erguidas pela Brazil Railway, sobrevivem ao tempo, como numa batalha simbólica em contraposição ao perigo do esquecimento e/ou ao risco do descaso, em relação a um passado que ainda não foi redimido. 0 Contestado ecoa em Santa Catarina, seja pela existência de marcos históricos ou pelas narrativas posteriores dos museus e demais monumentos que visam reconstruir, reelaborar uma memória da guerra. ${ }^{6}$

Sujeitos históricos destacados, no conflito e no movimento pela historiografia do Contestado, nomeiam ou já nomearam cidades (Matos Costa e Frei Rogério), bairros, ruas, emissoras de rádio, escolas, e, ainda aparecem como referenciais de diversos assentamentos rurais espalhados pelo Estado, a exemplo das comunidades chamadas: José Maria (Abelardo Luz), Maria Rosa (Passos Maia), São João I e II (Matos Costa), São João Maria (Papanduva); além da ocupação já consolidada, denominada Herdeiros do Contestado, localizada em Curitibanos. Forte indício de que os assentados se identificam e se reconhecem nos desalojados do passado.

Além da Universidade do Contestado, criada em 1990, que já teve e/ou ainda tem campus em diversos municípios, outras instituições e entidades privadas e públicas utilizam o vocábulo Contestado em seus nomes, respectivamente: a Fundação de Turismo Vale do Contestado (Conttur) - que, desde 1995, vem impulsionando o turismo histórico-cultural no

\footnotetext{
5 Em Três Barras, mais especificamente dentro do Campo de Instrução Marechal Hermes, atual propriedade pertencente ao Exército Brasileiro, encontram-se edificações originais da antiga sede da Lumber no município: hospital, escritório, armazém e moradia de um dos primeiros diretores, Sherman Bishop.

6 Tais monumentos podem ser encontrados nos municípios de Fraiburgo, Lebon Régis, Caçador, Irani, Curitibanos, Porto União, Calmon, Matos Costa, Canoinhas, Rio das Antas, Mafra, Santa Cecília, Irineópolis e Timbó Grande. (THOMÉ, 2004, p.121)
} 
Centro-Oeste catarinense ${ }^{7}$ e, o Instituto Histórico e Cultural da Região do Contestado, localizado em Caçador, desde 1989, com o intuito de incentivar manifestações e produções culturais, e apoiar projetos e iniciativas de preservação do patrimônio histórico-cultural existente na Região do Contestado (THOMÉ, 2004).

Citando apenas o caso do município de Caçador, o movimento social faz-se vivo e presente em estabelecimentos comerciais, culturais e turísticos, como na Ervateira Contestado, Livraria do Contestado, no Teatro do Contestado, no Hotel Esplanada do Contestado e até mesmo no CTG (Centro de Tradição Gaúcha) denominado Porteira do Contestado (THOMÉ, 2004). Componentes do patrimônio artístico-cultural, como telas, murais e painéis, representando personagens, fases ou episódios da guerra, podem ser admirados em algumas cidades, abrigados em instituições ou divulgados em exposições de caráter itinerante. ${ }^{8}$ Municípios catarinenses, que foram no passado cenário de episódios importantes da guerra e do movimento, contam anualmente com uma verba estadual para investir em diferentes opções de se "reviver" o Contestado, geralmente por meio de eventos ocorridos numa semana específica para tal finalidade: a Semana do Contestado, que mais adiante iremos novamente mencionar como parte das políticas de memória oficiais.

Tais formas de apropriação e "resgate" de memória, sugerindo reconhecimento, identidade, homenagem ou mero interesse comercial, são relativamente recentes. Até 40, 30 anos atrás, praticamente inexistiam referências a fatos e personagens da guerra.

Por décadas, o Brasil, o Sul, Santa Catarina e Paraná relegaram o Contestado ao esquecimento. Contudo, reminiscências do "tempo dos redutos" permaneceram como que atadas no interior das famílias sertanejas e foram transmitidas quase que somente para as suas gerações posteriores, uma vez que seus parentes protagonistas também se calaram no pós-guerra, receando revelar aspectos que pudessem custar suas próprias vidas, tiradas pela

\footnotetext{
${ }^{7}$ Em 1985, foi inaugurado o "Trem do Contestado", com trecho Matos Costa - Calmon - Caçador, numa iniciativa do Museu do Contestado de Caçador e da RFFSA.

${ }^{8}$ Como exemplo, o autor destaca o mural, criado pelo já falecido artista plástico Hassis, contendo sete seções que representam a guerra. Atualmente o mesmo encontra-se na Universidade do Contestado, campus de Caçador. (THOMÉ, 2004, p.109)
} 
forte repressão instaurada imediatamente após o conflito. Sobre uma espécie de "operação varredura" 9 , ou melhor, "limpeza étnica”, pós-agosto de 1916, narra Ivone Gallo:

Os grupos de escolta ambulante empreenderam uma campanha de extermínio contra os veteranos e testemunhas oculares da revolta cabocla. Ninguém sabia o porquê, mas a Polícia chegava, colocava os prisioneiros em fila, atirava e depois abandonava os corpos nos rios. Havia períodos em que a população não podia alimentar-se da carne dos porcos, porque esses animais alimentavam-se dos cadáveres, e, frequentemente, os cães retornavam para casa trazendo preso entre os dentes um membro humano mãos ou pedaços de pernas e braços. (1999, p.90)

Se no final da chamada República Café-com-leite, havia todo um silêncio sobre a revolta, nas décadas de 1960 e 1970, a situação não foi alterada. Machado (2004) cita o caso de Guido Wilmar Sassi, autor de Geração do Deserto, primeira obra literária sobre a guerra. 0 escritor, de Campos Novos (Santa Catarina) sofreu perseguição política pelo regime militar. Outro, segundo Machado, que teve sua produção cerceada pela ditadura foi Sílvio Back. 0 cineasta dirigiu, nos anos 70, o filme A guerra dos pelados, cujo roteiro foi embasado no livro de Sassi.

Pesquisadores que nos últimos anos tiveram o privilégio de entrevistar homens e mulheres que viveram nos redutos ou, na maioria dos casos seus descendentes, atestam o quanto tais pessoas haviam interiorizado a visão desqualificadora acerca do movimento, reproduzida pelos jornais e escritos militares da época e perpetuada por décadas.

Machado, ao realizar 28 entrevistas, sendo a maioria com filhos de pessoas que participaram ativamente do movimento ou combateram no lado adversário, concluiu que ainda existe na região uma dupla postura: “Em muitos casos, sentimos que não há mais 'vergonha' em se falar sobre a participação no movimento caboclo. Em outras situações, foi possível observar, ainda hoje, um forte preconceito contra descendentes de famílias que notoriamente participaram da vida nas 'cidades santas" (2004, p. 40).

0 mesmo autor ainda indaga: Até que ponto a existência de um projeto oficial de "Resgate da Memória do Contestado" foi capaz de operar alguma mudança significativa no processo de reelaboração da memória da segunda geração de caboclos?

A seguir, elucidaremos a origem de tal projeto, bem como as supostas finalidades do mesmo.

\footnotetext{
${ }^{9}$ Expressão utilizada por Nilson Thomé, para caracterizar a perseguição e eliminação, por parte do Exército e da Polícia de Santa Catarina, de todos os sobreviventes sertanejos que se destacaram nos piquetes e combates. Id., 2005, p. 37.
} 


\section{O FORJAR DE UMA IDENTIDADE}

O ex-governador, Esperidião Amin Helou Filho, incentivou uma série de projetos e produções sobre temáticas referentes ao Contestado. A partir do primeiro mandato de Amin (1983-1987) teve início, ainda que timidamente, um processo discursivo de exaltação dos sertanejos e da sua luta, por meio da valorização de elementos da cultura cabocla, como a forte religiosidade, a tradição comunitária, a harmônica relação com a natureza e o espírito de resistência e combate contra adversidades políticas, econômicas e sociais do tempo dos redutos.

Tal processo foi retomado durante seu segundo mandato (1999-2002), a partir da criação da lei estadual que implantou a Bandeira do Contestado (Lei n.o 12.060, de 18/09/2001), o mesmo símbolo usado pelos sertanejos durante a guerra, uma cruz verde sobre um fundo branco, e, a Semana do Contestado (Lei n.o 12.143, de 05/04/2002), entre outras realizações, que constituem as políticas culturais de memória.

Em ambos os mandatos, contudo, de modo mais acentuado a partir do segundo, encontramos muitas produções narrativas enaltecedoras dos sertanejos sobrepondo-se às imagens desqualificadoras ${ }^{10}$. Dito de outra forma, de fascínoras, ignorantes, fanáticos ou jagunços, os caboclos passam a ser representados como resistentes, bravos, combativos e até defensores da natureza, ou seja, qualificativos próprios de um processo de idealização, cuja tendência foi a de recair no mito do herói. Aliás, mitos são componentes imprescindíveis para projetos de identidade, como o existente no interior do projeto de "resgate" de memória do Contestado, dos governos de Esperidião, pois, o mito:

é, portanto um ficcionamento cujo papel é o de propor, ou mesmo de impor, os modelos ou tipos (...), tipos a serem imitados, dos quais um indivíduo - ou uma cidade, ou um povo inteiro - pode ele mesmo se identificar. Dito de outro modo, a questão que o mito põe é a do mimetismo, na medida em que apenas o mimetismo é capaz de assegurar uma identidade (NANCY, LACQUE-LABARTHE, 2002, pp. 32-33)

Em depoimento de próprio punho, Amin, justificou a necessidade de se recuperar a história do movimento.

\footnotetext{
${ }^{10}$ As primeiras imagens desqualificadoras surgem no período da guerra, principalmente por meio das narrativas da imprensa do Paraná e de Santa Catarina e também dos relatos militares. WEINHARDT, Marilene. Mesmos crimes, outros discursos? Curitiba. Ed. da UFPR, 2000. WOITOWICZ, Karina Janz. Imagem Contestada: A Guerra do Contestado pela escrita do Diário da Tarde (1912-1916). Ponta Grossa. Editora UEPG, 2014.
} 
(...) é antiga minha simpatia pela questão do Contestado, que vejo como um conflito ainda distante de ser resgatado para o devido conhecimento das novas gerações e como um episódio de profundo significado social, antropológico, cultural e humano da história catarinense. Em meu governo, em Santa Catarina, procurei promover esse resgate, estimulando estudos, provocando debates e realizando eventos que proporcionassem uma visualização efetiva de quem foi o homem do Contestado e como se processou sua relação com a terra, com o espaço circundante, com os opressores de seu tempo, e de que forma reagiu e marcou, pela sua luta, grande parte do que é Santa Catarina nos dias de hoje (VALE AMADO, 2002, p. 6)

Em outra passagem, o ex-governador aponta para a necessidade de um "novo diálogo" entre passado e presente:

\begin{abstract}
É preciso que alguém chame para si a função de interlocutor da voz dos vencidos - os homens, mulheres e crianças que resistiram à exploração, à espoliação, à opressão dos poderosos do começo do século XX, moldando um novo modo de vida que ainda se faz presente em parte significativa do território catarinense. 0 Contestado, registrado há quase nove décadas, ainda está vivo, e a lição deixada por seus protagonistas precisa ser entendida e apreendida cada vez mais e melhor (AMIN, 2002, p.34).
\end{abstract}

$\mathrm{Na}$ fala do ex-governador, o que sobressai é a defesa de que a cultura sertaneja, ainda que derrotada, sobrevive em parte do solo catarinense e que deve ser valorizada para poder ser absorvida pelas novas gerações. Desde a década de 1980, começou a defender que o homem do Contestado foi o mais típico dos catarinenses. "Vejo a sua luta de 70 anos atrás, como a luta de inúmeros 'catarinenses' de hoje, e, mais, luta de milhões de pequenos em todo o mundo" (AMIN, 2002, p.34) Segundo Amin, o típico catarinense não pode ser visualizado no homem do litoral, de cultura predominantemente europeia; muito menos no homem serrano, de influência gauchesca; nem mesmo no homem oestino, proveniente da fusão das culturas europeia e gaúcha; mas sim, no homem do Contestado.

Ao criar um tipo ideal de catarinense, Amin também parece idealizar aquele que afirma ter sido seu predecessor, ou seja, aquele que lutou contra tudo e contra todos para defender uma série de valores, não reconhecidos pela sociedade de seu tempo, porém herdados por alguns segmentos da sociedade catarinense atual.

As representações delineadas por Amin apontam para a existência de alguns laços identitários entre o referido homem do Contestado e parte da população do atual estado de Santa Catarina. Promover e gerir oficialmente esses laços identitários, em direção à construção de uma da identidade, através da memória, passa a ser uma das finalidades maiores do Projeto de "Resgate" da Memória do Contestado. ${ }^{11}$, ao menos no campo discursivo

\footnotetext{
11 Nome oficial do projeto que deu sustentação às políticas de memória e identidade.
} 
do próprio governador, como o documento atesta. Pois, algumas das produções e manifestações materializadas no espaço, decorrentes dos investimentos e financiamentos por parte do governo estadual, contrariam o discurso de Esperidião Amin ao reproduzirem ainda, de modo explicito ou nas entrelinhas, elementos das velhas narrativas pré-conceituais, acerca do mundo sertanejo, ou ainda, ao promoverem uma valorização do lado vencedor. Não rompendo, portanto, com uma visão que, ao não problematizar continua: desqualificando a cultura e resistência sertaneja e mais parece uma homenagem ao lado vencedor. Desse modo, a proposta de um novo diálogo entre passado e presente, anunciada pelo ex-governador, é realizada apenas de modo parcial, pois a memória apropriada pelas políticas oficiais, não é homogênea e nem todas as narrativas podem ser interpretadas como interlocução da voz dos vencidos. Nesse ponto são significativas as análises críticas de Susan de Oliveira, uma das precursoras no pensar de modo crítico os "lugares de memória" criados a partir da gestão de memória no estado de Santa Catarina. Por ocasião da elaboração de sua tese de doutorado, a autora desvenda elementos - muitos dos quais ainda persistem na configuração espacial do Museu do Contestado no município de Caçador - de supervalorização acrítica dos signos da modernidade, (como o prédio réplica da Estação Ferroviária, a locomotiva a vapor, o obelisco da Aviação Militar e a denominação Achilles Stenghel, diretor da Brazil Railway, ao edifício que sedia o acervo do Contestado) como monumentos em homenagem aos vencedores da guerra, como monumentos que reproduzem a lógica da relíquia, "privatizando" a memória do conflito de acordo com os interesses dos que ainda ocupam o poder, no caso interesses não divergentes dos vitoriosos ao fim do conflito, como o Exército brasileiro e o grupo norteamericano (OLIVEIRA, 2006)

A autora também questiona a proposta não efetivada do historiador Nilson Thomé de "retomar" os antigos caminhos usados pelos caboclos do Contestado para fugir das forças de repressão, transformando-os em campos de peregrinação rumo a um empreendimento turístico, assim, deslocado de vivências e prerrogativas das comunidades existentes no presente na Região do Contestado, e, centrado no desfrute individual e em vantagens para o mercado local.

Mais recentes são as reflexões do historiador Rogério Rosa no XV Encontro regional de História, intitulado 100 anos da Guerra do Contestado: historiografia, acervos e fontes, realizado nos dias 26 a 29 de julho de 2016, pela ANPUH. Rosa, professor doutor, da UDESC, selecionou algumas produções do governo do estado de Santa Catarina, realizadas no 
contexto do Centenário do Contestado, para análise. Entre elas, um documento digital, um site de divulgação turística do chamado Vale do Contestado no qual, de acordo com ROSA, a guerra, o movimento e a cultura sertaneja são ofuscados pelo predomínio de referências à colonização europeia da região. Embora o texto de apresentação contenha um parágrafo afirmando que alguns municípios preservam, através de museus, sítios históricos e caminhos de peregrinação, a memória do movimento e da guerra, a seleção de imagens apaga a resistência e a cultura cabocla, direcionando a ideia de potencial turístico da região para atrações relacionadas à cultura do imigrante. Exceto pela foto do monumento símbolo de Irani, chamado Mãos de Cimento, as imagens silenciam sobre a tragédia vivida, não aparecem crematórios, cemitérios, museus e nem ao menos remanescentes dos sertanejos.

De acordo com Thomé (2004, p. 25), diversas realizações a respeito do conflito ocorreram ainda na primeira gestão de Amin, inclusive o desenvolvimento de seu próprio projeto, igualmente intitulado Resgate da Memória do Contestado. Como exemplo, o historiador falecido em 2014, cita: a implantação do Museu do Contestado, em 1985, na cidade de Caçador, edição de livros e álbuns, produção de discos e documentários, além da realização de congressos e simpósios.

Museus, monumentos, produções científicas e artísticas foram instrumentos utilizados para se reelaborar uma memória para o Contestado. Entretanto, não podemos pensar num todo homogêneo, existem discursos e narrativas presentes nos "lugares de memória"12 que são divergentes e contraditórios, quando interpretados entre si e no conjunto das políticas de memória, principalmente em relação à proposta inicialmente apresentada pelo governador Mais coerente com a fala de Amin, encontramos as representações contidas na produção cultural e no trabalho de manutenção dos monumentos realizado por Vicente Telles. Escolhemos Telles pelo caráter precursor e singular de sua obra, a qual desde os anos 70 até o presente momento esteve voltada para "instituir" uma memória propícia à elevação da condição dos sujeitos históricos que combateram e morreram, infundindo-lhes valores e sentimentos enaltecedores em substituição a visões e concepções que, até então, encerravam os mesmos em compartimentos depreciadores, tratando-lhes como incautos, desordeiros, fascínoras, meros fanáticos ou jagunços. Telles, sem formação acadêmica, foi um dos

\footnotetext{
12 Categoria analítica, aporte conceitual ou simplesmente noção, o termo criado pelo historiador francês Pierre Nora ultrapassou os limites historiográficos, caindo no uso comum. De acordo com Nora, são lugares de ritual, onde a memória poderia se cristalizar, porém, o que encontramos neles é mais história reconstruída (a partir de necessidades do presente) ou ainda uma memória historicizada, do que propriamente memória. Tais lugares comportam sempre a "vontade de memória" ou a "intenção de memória".
} 
primeiros a entender a complexidade das questões sociais que geraram a resistência sertaneja, bem como o importante papel da religiosidade na ação política do movimento e a visão de mundo dos caboclos.

\section{RETALHOS DO CONTESTADO13 EM IRANI}

O interesse de Vicente Telles pelo Contestado é anterior ao primeiro governo Amin. 0 primeiro evento pensado, organizado e realizado pelo folclorista sobre a temática data de 1979. Ano em que a população de Irani assistiu, durante o desfile de 7 de setembro a uma dramatização, representando um dos fatores que desencadearam o movimento e a guerra. Entretanto, foi a partir do "resgate" histórico-cultural, promovido por Esperidião Amin, que a obra de Vicente ganhou certa notoriedade, ultrapassando os limites municipais para tornar-se conhecida no Estado e até em outras cidades do Sul.

Em Irani, monumentos, como o próprio Museu do Contestado (também conhecido, por Museu José Maria), a gigante escultura "Mãos de Cimento", a preservação do Cemitério do Contestado, bem como o projeto do Parque Temático do Contestado, foram iniciativas que resultaram da parceria Telles e Amin.

O parque, planejado para ocupar uma área de $318.031,35 \mathrm{~m}^{2}$, estava sendo implantado às margens da BR 153, Km 63 e foi concebido para funcionar como um centro de estudos, apresentações culturais e, principalmente, uma referência para o turismo histórico-cultural, capaz de diferenciar Irani dos demais municípios catarinenses.

Por várias vezes, Amin e Telles chegaram a somar esforços em prol da causa do Contestado. 0 que não é de se estranhar, uma vez que encontramos ideias e concepções, isto é, representações comuns nos discursos de ambos. Exemplificando, a mitificação dos rebeldes caboclos e a visão do homem do Contestado, como já mencionamos na fala de Amin, são complementares aos termos, imbuídos de heroísmo, usados pelo folclorista como saga e épico, para caracterizar ações, direcionamentos e atos daqueles que viveram e lutaram nos redutos. Vicente declara que os sertanejos, seguidores de José Maria, foram extremamente heroicos

\footnotetext{
${ }^{13}$ Retalhos do Contestado é o título de uma música do CD Epopeia do Contestado - História em Música
} 
por terem legado ao Brasil essas terras, fertilizando com o próprio sangue o solo, isto é, morrendo para defendê-lo dos interesses estrangeiros e dos usurpadores de seu tempo ${ }^{14}$.

Em posse dos vídeos com filmagens de desfiles e outros eventos, fotografias, músicas do CD Epopeia do Contestado - História em Música, entrevistas com o autor, matérias em jornais, depoimentos de outras pessoas e textos em livros de outros autores, que mencionam as ideias do folclorista, fomos buscar as formas de representação, que acreditamos compor o imaginário da guerra em Irani, sem perder de vista, os dois pólos de interpretação existentes no imaginário catarinense atual: a detração, construída a partir das velhas narrativas da imprensa, Igreja, relatos militares, da época do conflito, intensificada pela repressão após o término do guerra e, não ultrapassada por parte da historiografia, e, a idealização contida em vários discursos perceptíveis nos "lugares de memória"

\section{VIDA E OBRA ENTRE CORONÉIS, JAGUNÇOS E MILITARES: O HOMEM E O ARTISTA VICENTE TELLES}

Em cada um de nós jaz a memória de nossos ancestrais. (Jorge Luis Borges)

Vicente Telles nasceu em Palmas, Paraná, no dia 5 de outubro de 1931. Viveu boa parte da infância no município de Irani, dos cinco anos de idade até os dezoito, quando passou a servir ao Exército, ausentando-se para voltar somente em 1976, na condição de sargento aposentado. Conta Vicente que, no mesmo ano, por ocasião da construção da BR 153 - a qual passou a cortar a cidade, inclusive a área da propriedade em que mora até hoje - teria conhecido engenheiros que lhe relataram motivos, fatos e detalhes trágicos da guerra, nunca comentados pela população local. Referindo-se às permanentes interdições do pós-guerra, Telles comenta: "Antes, na minha infância, era proibido falar sobre o assunto sob pena de perseguição e castigo pelos remanescentes da opressão, inclusive pelo meu avô paterno". ${ }^{15}$ Neste ponto, Vicente refere-se aos laços consanguíneos que atam sua vida pessoal à Guerra do Contestado. 0 autor é neto, por parte de pai, do casal Alexandre Telles da Rocha e Arminda Fabrício das Neves, proprietários de terras que, na época, posicionaram-se, como ele mesmo

\footnotetext{
${ }^{14}$ Entrevista gravada na casa de Vicente Telles - Julho de 2006. 3 cassetes sonoros

15 Citado por Vicente Telles na ficha de dados respondida em setembro de 2006.
} 
diz, ao lado do coronelismo opressor, e, por parte de mãe, de José Alves Perão e Júlia Olímpia da Silva, ambos sertanejos simpatizantes e defensores dos caboclos que seguiam o monge José Maria. Apesar de ter herdado as terras onde mora da família de seu pai e de utilizar o sobrenome do avô, Vicente, em várias passagens durante as entrevistas, demonstrou se identificar com o lado materno da família, afirmando ser "um pouco da voz do sangue caboclo que foi derramado no solo contestado". 16

Voltando à descoberta do Contestado, Telles afirma que a "versão dos vencidos", sustentada pelos engenheiros, não era a mesma encontrada na maioria dos livros sobre a Campanha do Contestado. Na época, existiam poucas publicações que abordavam apenas os grandes feitos dos generais e os sofrimentos dos militares, como: marcha forçada, ataques por meio de tocaias, fome, frio e lama. Em contrapartida, as mesmas retratavam os caboclos como bandidos, bandoleiros e fanáticos.

Das conversas com os engenheiros, Vicente afirma ter nascido um sentimento de indignação que o levou a pesquisar mais e mais sobre o Contestado. Nas palavras do próprio autor, com o passar do tempo: "O ardor foi crescendo e o anestésico para as dores era encontrado nas reflexões acerca de meios e formas de levar ao povo aquilo que era objeto das elites de gabinete" 17.

Três anos depois, em setembro de 1979, nasceria a ideia e a oportunidade de seu primeiro trabalho em prol do Contestado. No entender de Vicente, uma reconstituição cênica simbolizando a expulsão, isto é, o desalojamento dos caboclos de suas terras, em decorrência das ações do grupo estrangeiro. Sobre a origem da realização, ele mesmo relata:

Um dia chegou na minha casa, um grupo de senhoras humildes, assim dessas bem caboclas da época do Contestado. Não eram negras, não eram brancas, não eram mulatas, nem roxas. Mas, sim um tipo de pinhão desbotado. Aí, elas chegaram, algumas descalças, outras não e uma delas falou: - Seu Vicente, o senhor se dá bem com a diretora do colégio, a freira, não? Ela quer que a gente compre roupa nova para desfilar no dia 7 de setembro. Nós não temos dinheiro. Então respondi: - Olhe, eu não sei, mas se a diretora autorizar, eu vou fazer algo diferente (...) Eu vou com vocês. Nós vamos todos esfarrapados, de caboclos, desfilar. Vocês topam? Reuni aquelas mulheres e fui falar com a freira. Expliquei que elas iam representar a dignidade do povo que nos legou aquelas terras. Mas, elas tinham que ir esfarrapadas. Quanto mais esfarrapadas, melhor. No dia, foram levando cachorro, porco e cabrito puxado, panelas indicando mudança. Aí arranjei um cavaleiro para fazer o papel do monge a cavalo. Foi lá, também, uma virgem com vestido e cavalo branco. Consegui uma camionete com auto-falante. Na hora que entramos, comecei a falar, a discursar. Disse que essas eram as raízes da nossa história, raízes desconhecidas pelo povo atual. Por isso, afirmei que

\footnotetext{
16 Idem

17 Idem
} 
precisávamos mostrar o que foi (...) De onde viemos. Quem foi o povo que deu ao Brasil essa terra. E o que ele recebeu em contrapartida. Em compensação, disse que foram as balas das metralhadoras da Velha República. E até hoje são tidos como jagunços, bandidos e fanáticos. Se fossem ricos, seriam considerados piedosos, devotos. Mas como eram pobres foram considerados fanáticos. (TELLES, Vicente: depoimento julho, 2006)

A respeito de como a encenação e o discurso repercutiram naquele momento em Irani, Telles relembra com risos, mencionando que ouviu gente vaiando e gritando para chamar a polícia, até que um promotor público, Alexandre de Queirós, acalmasse os ânimos em defesa do que seria apresentado. ${ }^{18}$

Apesar da perplexidade de muitos, dali em diante, Vicente foi incumbido e se incumbiu do que acredita ser parte maior de sua missão de vida, ou seja, popularizar o Contestado e o Combate do Irani. Desde então, foram criados mais de trinta quadros cênicos, dentre os quais ele mesmo destaca: o dos Três monges, o dos Doze Pares de França, do Ervateiro, dos Escorraçados, das Virgens, além de encenações sobre as atuações daqueles que considera verdadeiros heróis, como: o capitão Matos Costa, o Menino Deus, o Imperador Manoel Alves de Assunção da Rocha e a última liderança cabocla - Adeodato. Tais quadros foram apresentados em desfiles, compondo as encenações, ou ainda isoladamente, em auditórios, escolas, colégios, teatros ou ao ar livre, tanto em Irani quanto em outras cidades de Santa Catarina. No início, os desfiles ocorriam apenas na data de 7 de setembro. Com a criação governamental da Semana do Contestado, os mesmos passaram a ser realizados num dos dias de 20 a 27 de outubro, período de execução da Semana Cultural do Contestado em Irani.

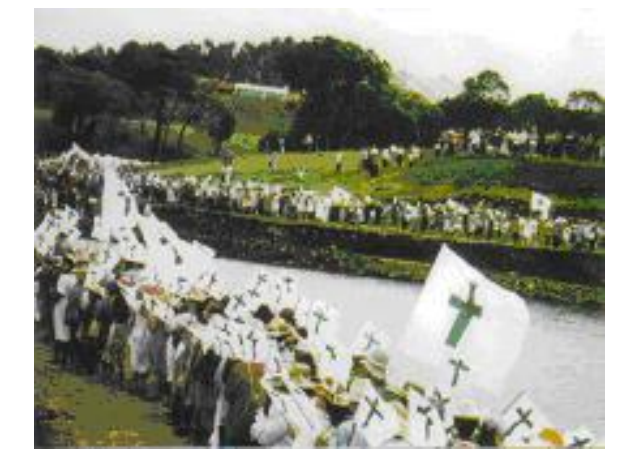

Desfile em Irani, realizado no mês de outubro, durante a Semana do Contestado. Impresso promocional Prefeitura Municipal de Irani - Fundação Cultural Memória Viva do Contestado - Região do Irani.

18 Ibid. 
De acordo com o autor, inicialmente não foram poucas as resistências às suas propostas de trabalho. "Essas manifestações levaram-me ao conceito de louco, visto que ninguém, a rigor, sabia nada da história em nossa região".19 Além de louco e excêntrico, Vicente também foi chamado de mentiroso, muitos acreditavam que ele inventava os episódios da guerra que foram abordados nas dramatizações.

Mesmo sem a favorável unanimidade do município, foram realizados em Irani, por muitos anos, desfiles, nos quais o folclorista passou a envolver professores, alunos, simpatizantes locais e autoridades municipais e estaduais. Quando Amin tornou-se governador pela primeira vez, conta Vicente: "começamos a fazer festas dentro dessa propriedade" 20. Apontando em direção às próprias terras, o autor prossegue: "Um trem alegórico foi construído e passou a desfilar em volta do lago lá em cima. Nunca fizemos um desfile com menos de 2.500 pessoas, todas alegorizadas". ${ }^{21}$

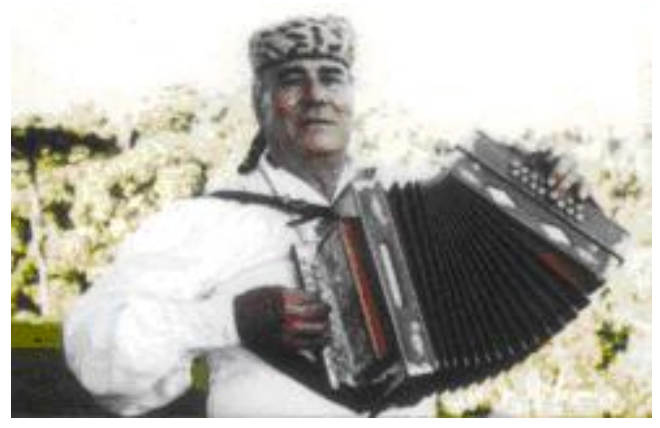

Epopeia do Contestado- História e Música, 2002.

Incompreendido por alguns moradores e atacado por alguns políticos, o folclorista teve que esperar pelo reconhecimento externo, via mídia, para ter maior aceitação dentro de sua própria cidade. Sobre a gradativa aceitação, o mesmo comenta:

A imprensa e a televisão começaram a divulgar os desfiles. E aí, muitos repórteres tinham bom senso, ressaltando a versão dos vencidos. E começou a inflamar a região. E onde tem povo, tem força e onde tem essa força, tem político. E o que aconteceu? Os caras quiseram me combater. Me chamaram até de Joãozinho Trinta de Irani. Mas, quanto mais me combatiam, mais curiosidade (...) Porque é o princípio da filosofia

\footnotetext{
${ }^{19}$ Citado por Vicente Telles na ficha de dados respondida em setembro de 2006.

${ }^{20}$ Idem

${ }^{21}$ Idem
} 
americana: 'fale mal, mas fale'. Foi tudo isso que me deu vontade de continuar (...) Foi tudo isso que fez a ideia do Contestado surgir em Irani. ${ }^{22}$

Vicente prossegue argumentando sobre o principal motivo da atual aceitação: "Eles aprovam porque percebem que está todo mundo a favor, o pessoal que vem de fora (...). Eu recebo aqui, três a quatro ônibus por semana"23, numa referência ao que chama Projeto pedagógico Folclore do Contestado.

Quanto ao envolvimento da população mais humilde do município, de origem cabocla, com os eventos destinados a promover o Contestado, encontramos a participação nos desfiles até de ex-combatentes, como Neco Germano, falecido em 1982, cuja fotografia dele acompanhado de mais duas senhoras em cima de um carro de som, aparece no encarte que acompanha o CD Epopeia do Contestado - História em Música. O próprio Vicente conta que muitas das fotos que formam o acervo do museu foram compradas por ele, de pessoas que desfilaram em anos anteriores. Estas, segundo Vicente, já haviam se libertado dos sentimentos de medo e vergonha por terem, no passado, assumido a posição de rebeldes, ou ainda por serem descendentes do povo dos redutos. Fatos comprovados pela participação das mesmas nas reconstituições de época, criadas pelo autor, e também por venderem tais registros, sabendo que o destino dos mesmos seria o de ir para um museu.

Em Irani, quando perguntávamos sobre Vicente em certos estabelecimentos, como restaurantes, lojas, lanchonetes e hotel, as informações que obtínhamos eram semelhantes. Os proprietários e/ou funcionários eram praticamente categóricos em afirmar que o folclorista entendia muito sobre o Contestado. Também falavam que se o projeto do Parque Temático do Contestado desse certo, o município entraria numa fase de desenvolvimento que seria positivo para a população.

\title{
IRANI: BERÇO DA CULTURA VIVA DO CONTESTADO
}

\author{
Combate do Irani
}

Eu conto um pouco da história desta terra

Palco de guerra de heroísmo e altivez

Do Irani que abrigou durante a guerra

Numa luta pela terra sertanejo e camponês

\footnotetext{
22 Idem

23 Idem
} 


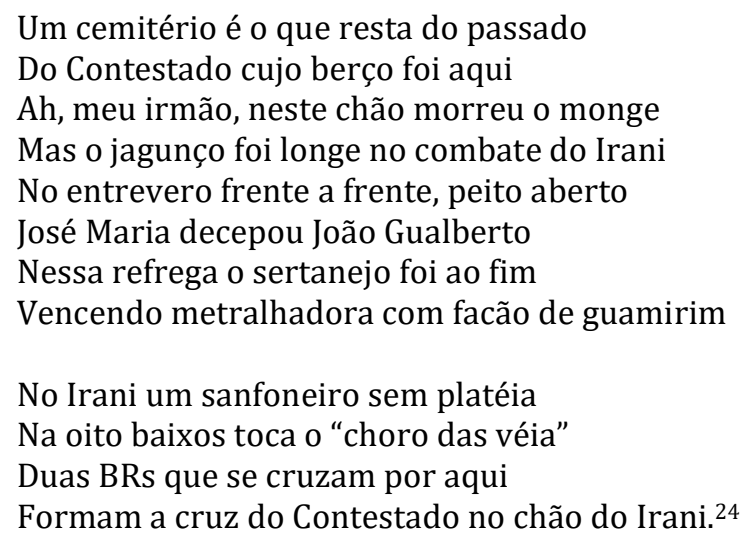

A letra da música sugere que o chão de Irani vivenciou uma luta desigual, dos "grandes" contra os "pequenos", da autoridade militar contra o líder espiritual dos sertanejos e camponeses, dos que estavam bem armados contra aqueles que improvisavam. 0 heroísmo e a altivez residem no fato dos caboclos terem vencido o combate. No ato do monge que tirou a vida do comandante, mesmo morrendo depois e, no triunfo do facão de guamirim sobre a metralhadora. ${ }^{25} \mathrm{Na}$ mesma, o episódio do Irani não parece ser representado como uma mera batalha que prenuncia a guerra, que viria um ano depois, mas sim, aparenta ser a própria guerra em andamento.

Sobre a importância do Combate do Irani, Nilson Thomé e Vicente divergem. Segundo o historiador de Caçador, a guerra não começou a partir do episódio do Irani, versão que para ele possui um enfoque militarista, sendo defendida por alguns escritores paranistas a fim de promover e imortalizar a figura de João Gualberto (THOMÉ, 2004, p.67). Já para Vicente, o Contestado tem sua origem em Irani, município onde se deu a batalha inicial da guerra, a qual vitimou os dois "heróis", cada qual, na época, referencial do seu estado: para os sertanejos o monge José Maria e para as autoridades e militares paranaenses o comandante Gualberto.

Tais imagens discordantes são indicativas da disputa simbólica entre municípios catarinenses, que buscam, cada um à sua maneira, legitimar a importância que tiveram no passado, enquanto regiões onde existiram redutos ou ocorreram combates. Os sertanejos, que foram no passado por tanto tempo esquecidos, e somente lembrados para serem desalojados, hoje são objetos de disputas, visíveis nos conteúdos dos impressos promocionais tanto de

\footnotetext{
${ }^{24}$ Letra e música integrantes do encarte e CD Epopeia do Contestado - História em Música.

${ }^{25}$ A indicação de que José Maria tenha, com sua espada, matado João Gualberto provavelmente faz parte da tradição folclórica na região, não encontrando veracidade em registros.
} 
Caçador quanto de Irani. No folder de divulgação do Museu Histórico e Antropológico da Região do Contestado, um dos principais componentes do turismo cultural oferecido pela cidade de Caçador, a capa traz uma fotografia da sede própria que abriga o acervo, denominada Edifício Achilles Stenghel, acompanhada da seguinte frase: "Museu do Contestado: aqui o contestado se faz história”. Já os dois folders de Irani trazem a mesma foto do monumento "Mãos de Cimento" e logo abaixo a frase-título: "Berço da Cultura Viva do Contestado". Um deles é específico sobre o papel de Irani no Contestado, trazendo a cronologia da guerra, uma narrativa do combate, intitulada A jornada heroica de Irani e bibliografia correspondente ao mesmo. 0 outro fornece um breve histórico do território e da criação do município, bem como oferece uma mostra das paisagens naturais, das opções de lazer, do patrimônio histórico e das festas realizadas na cidade, destacando o Contestado por intermédio de fotografias do cemitério, do museu e do Parque Temático.

A importância que Telles confere ao município, enquanto local de origem do primeiro combate da guerra, encontra respaldo em parte da população e no projeto da Prefeitura Municipal, de se vincular a imagem de Irani à Guerra do Contestado, a fim de promover o turismo histórico no município. 0 conteúdo do texto, intitulado A heroica jornada de Irani, encontrado em um dos folders, compartilha as ideias que Vicente deixou transparecer nas entrevistas e na letra da música. A frase "Berço da Cultura Viva do Contestado" parece ter saído diretamente do autor, uma vez que o próprio exigiu que o nome da fundação que atualmente preside fosse Fundação Cultural Memória Viva do Contestado da Região de Irani, para justificar ações "vivas" da cultura, em contraposição à cultura que acredita "estar morta, isto é, limitada aos gabinetes eruditos, aos livros e às conferências inacessíveis ao povo" 26.

Irani e o monge José Maria, que morreu em terras do atual município, ainda sobressaem nas representações de Telles sobre os três andarilhos, isto é, os três monges.

\section{O SANTO, O POLÍTICO E O GUERREIRO}

Vicente parece ter traçado uma espécie de tipologia dos três monges, perceptível tanto em sua fala, durante as entrevistas, quanto na letra de uma de suas músicas. Quando perguntamos qual o envolvimento que ele teve com a concepção do monumento Mãos de

\footnotetext{
${ }^{26}$ Citado por Vicente Telles na ficha de dados respondida em setembro de 2006.
} 
Cimento, Telles respondeu que na época teve uma ideia, pensou num símbolo para o Contestado; ele nos relatou assim:

\begin{abstract}
Digamos que aqui tenha um poste. Do lado do poste, o primeiro monge com a Bíblia nas mãos, porque ele veio e deixou um carimbo de santidade e pregou a palavra de Deus. Até porque era remanescente de uma ordem religiosa. Até aí confere com a história. No segundo poste, Anastás Marcaf, que se dizia nascido no mar e criado em Buenos Aires, veio nas hostes de Gumercindo Saraiva. Era fanático de Gumercindo, inclusive dizia que Gumercindo ia ressuscitar, já tinha ressuscitado; era muito político. E no terceiro, lá na cúpula, José Maria, o guerreiro com a espada. Eu tenho a impressão que não tem símbolo mais significativo do que esse. A ideia é a dos três monges: dois Joãos e um José, todos Maria, caracterizados pelo três elementos: o santo, o político e o guerreiro. ${ }^{27}$
\end{abstract}

Podemos interpretar, na letra da música Epopeia do Contestado, transcrita na sequência, que cada monge surgiu num momento condizente com suas características e habilidades pessoais. 0 "monge santo" apareceu no contexto do povoamento daquela que foi concebida como a "Terra Prometida", disseminando entre o povo práticas e sentimentos religiosos, adequados, portanto, à imagem bíblica correspondente. 0 "monge político", revestido de maragato, surgiu na vigência da experiência republicana, no início do processo espoliador, legando aos sertanejos anseios de liberdade. E, por último, o "monge guerreiro" que veio para reunir os excluídos, os desalojados, conduzindo-os à terra das visões, ao Irani, “Terra Santa”, terra da fartura, terra que foi defendida a facão.

Epopeia do Contestado

Eram dois povos - duas histórias -

Um além-mar, outro cá do sertão.

Trocando amores, uniram destinos

Povoando a terra da promissão

E foi aí que surgiu João Maria,

O monge santo, ensinando a oração,

A crença fiel no poder divino,

Fé e esperança no eterno destino.

Mas a ganância dos poderosos

Quis suas terras, roubou seu sertão

Fez minha gente humana boiada

Tangida a bala, sem rumo e sem chão

E apareceu novo São João Maria

Do monge Santo dizendo-se irmão,

Um maragato que ao sertanejo

Deu forte desejo de libertação

Veio o terceiro monge guerreiro

27 Entrevista gravada na casa de Vicente Telles/Julho de 2006.k 


\author{
Juntando os párias do vasto sertão \\ Que, visionários da terra santa, \\ Lá (cá) no Irani escolheram seu chão. \\ Plantando ao sol, rezando ao luar, \\ Nos campos fartos de gado e pinhão, \\ Mas do poder que os fere sanhudo \\ 0 fuzil ficou mudo, falou o facão. \\ A Guerra Santa durou quatro anos \\ E avermelhou o meu verde sertão, \\ Perdeu-se a luta, ganhou-se a causa: \\ Nosso direito à fatia do chão. \\ Com a memória de Zé Maria \\ Monge guerreiro em todo rincão, \\ Do entrevero peludo-pelado \\ É o Contestado a grande lição. ${ }^{28}$
}

A guerra foi duradoura e violenta, banhou de sangue todo o sertão. 0 caboclo perdeu, mas o catarinense atual desfruta da causa, adquirindo seu pedaço de chão. Além da terra novamente dividida - em referência aos minifúndios existentes no estado, desde o processo de colonização por imigrantes europeus - restou a lembrança e a lição, ambas deixadas pelo monge guerreiro e pela experiência do Contestado. Desse modo, o autor exalta José Maria, como exemplo de coragem, bravura, determinação e sabedoria. "Um homem que tinha conhecimento da medicina empírica, um homem que tinha conhecimento dos problemas sociais, um homem que tomou as dores do povo". ${ }^{29}$ Segundo Vicente, o bom caráter do monge deveria ser um fato inquestionável, uma vez que o mesmo: "Curou a mulher de um fazendeiro. Quando o fazendeiro quis gratificá-lo com 30 alqueires de terra, ele não aceitou. Ao ser interrogado sobre o motivo da recusa, ele respondeu: Eu, quando morrer, não levo terra nem pasto na boca. ${ }^{30}$

O desapego material que Telles atribui a José Maria ainda é representado na música a seguir:

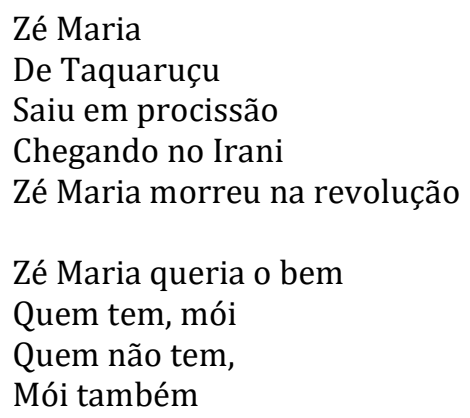

\footnotetext{
${ }^{28}$ Letra e música integrantes do encarte e CD Epopeia do Contestado - História em Música.

${ }^{29}$ Entrevista gravada na casa de Vicente Telles/Julho de 2006.

30 Idem
} 
Quem tem, mói

Quem não tem, mói também.

Disse mais: e no fim todos ficam iguais. ${ }^{31}$

A frase indicativa do espírito de igualdade pode ser vista como um ensinamento do monge aos seus seguidores. 0 senso desprovido tanto de ambição quanto de caráter de acumulação, existente na vida comunitária dos redutos, aparenta ter sido apreendido diretamente da mensagem deixada por José Maria aos que ficaram, como atesta Vicente, "órfãos de liderança espiritual, militar e política".32

Monge guerreiro, monge mártir, monge santo. Novamente três imagens, que se sobressaem, até mesmo quando Vicente acompanha os alunos ao local da sepultura de José Maria, como tivemos oportunidade de assistir. Assim que os estudantes chegam, o músico pede silêncio, respeito, e tem início uma espécie de cerimônia, na qual, ao som da gaita, os alunos cantam, invocando o monge. No local, existem três cruzes, rodeadas de pedras - duas delas inclinadas, parcialmente plantadas no solo, simbolizando os dois monges anteriores, cuja morte e destino dos corpos permanecem obscuros - e uma, dedicada a José Maria, encontra-se ereta bem em frente ao que supostamente corresponde à sepultura.

\section{OS PUROS DE MENTE, ALMA E CORAÇÃO}

Além de bravos, corajosos e valentes, o autor ainda atribui aos caboclos uma extrema pureza verificável nos gestos e sentimentos. Referindo-se tanto aos sertanejos do passado quanto aos que ainda vivem pelo interior, Telles afirma que muitos intelectuais não conseguiram, e ainda não conseguem, captar quem foi e quem é o caboclo. Em contrapartida, defende:

Nós temos que nos despir, talvez, até dos cinco sentidos para captar a realidade desse homem. Você vai analisar a história do povo dos redutos, então, primeiro ponha sempre quem é o caboclo. Eu sou neto de caboclo. Eu fui madrinheiro de tropa. Eu andei por esses sertões, por esses caminhos perdidos, por aí, ouvindo a pureza da

\footnotetext{
${ }^{31}$ Letra e música integrantes do encarte e CD Epopeia do Contestado - História em Música.

${ }^{32}$ Citado por Vicente Telles na ficha de dados respondida em setembro de 2006.
} 
mente, da alma e do coração dessa gente. 0 amor deles para com o semelhante e para com a natureza. ${ }^{33}$

Em contrapartida aos argumentos que resumem os caboclos do movimento a meros saqueadores, em alusão aos piquetes, Vicente procura esclarecer, desvendando a concepção de vida dos acusados do passado:

O caboclo nasceu num meio onde o que era de um era de todos. Tudo que tinha aqui, tinha gado, era coalhado de gado selvagem, tudo era usufruído por todos. Aí, os coronéis passaram a recolher o gado e a marcá-lo, a cercar a terra. Como tinha gado sobrando e terra à vontade, ninguém se importou. Mas quando começou a guerra e veio a fome, eles passaram a atacar as fazendas para recolher aquilo que era deles. Não é que eles fossem maus. Tudo isso era apenas uma herança de educação, de formação. Eles tinham esse espírito. Quem pesquisa tem que enfocar esses pontos. ${ }^{34}$

Vicente legitima a ação dos piquetes com base numa análise nada superficial do modo de vida e imaginário caboclo. Embora entenda os reais motivos de algumas práticas e ações dos sertanejos, ultrapassando visões simplistas e preconceituosas, não deixa de recair num outro extremo: o da idealização. Tal idealização, contudo, é suavizada quando o autor compara os desalojados do Contestado aos integrantes do Movimento dos Sem-Terra. Para Vicente, a diferença entre os sem-terra de hoje e os sertanejos do Contestado, é que:

(...) os de hoje são escorraçados voluntários. Eles têm consciência dos direitos. E se organizam para lutar por esses direitos. 0 que faltou no homem do Contestado foi organização. Se eles tivessem a consciência que se tem hoje (...). Tinha gente valente, gente inteligente, mas não tinha essa experiência de hoje. 0 amparo legal que se tem hoje, sindicatos, organizações que se tem hoje. ${ }^{35}$

Falta de organização, de experiência ou inexistência do amparo da lei? Aqui, Vicente apresenta um discurso ambíguo, ora constatando uma incapacidade de organização por parte dos desalojados de "ontem", ora destacando as diferenças por meio das possibilidades do tempo presente, ou seja, citando instituições que representam os interesses dos despossuídos, que se quer existiam no passado.

Em dois fragmentos da música Rapsódia do Contestado, Telles estabelece a relação, o "encontro" entre dois, ou melhor, três tempos históricos:

\footnotetext{
${ }^{33}$ Entrevista gravada na casa de Vicente Telles/Julho de 2006.

${ }^{34}$ Idem

35 Idem
} 


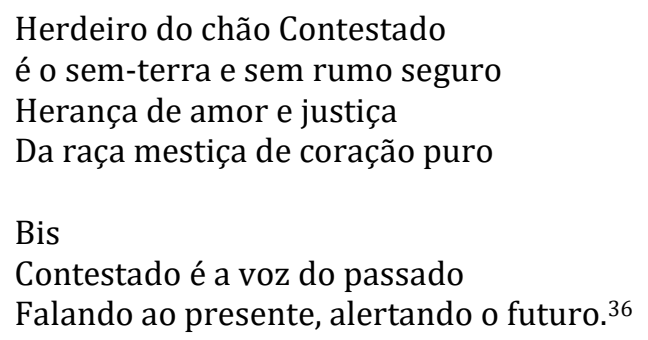

Além da já mencionada idealização, podemos captar o esboço de uma certa continuidade, seja pela permanência do problema social - ainda existem aqueles que não têm acesso à terra - ou porque os despossuídos do presente herdaram o mesmo espírito de luta, a mesma sede de justiça dos sujeitos históricos do passado. Nos dois casos, o Contestado está "vivo", está presente no "agora", como que fornecendo ao futuro sua lição, sua experiência histórica.

Conforme afirma Vicente, o maior legado dos sertanejos que viveram nos redutos, transmitido à posteridade, foi o catecismo cívico, composto de ensinamentos de amor à terra, à natureza circundante e à pátria. No dizer do autor: "Nós temos é que mostrar o catecismo cívico do caboclo, incorruptível da honra e invencível na dignidade" (...) "Quem não reverencia seus mortos, seu passado, sua história, perde um pouco da dignidade da pátria".

\section{O CATECISMO POR MEIO DA ARTE E DA HISTÓRIA}

De acordo com o autor, a construção do civismo passa pela questão do sentimento. Sentimento associado à conscientização, à consciência. "Cheguei à conclusão de que é preciso se criar um sentimento em torno do Contestado. Sentimento não de ódio, de revolta, de indignação ou de vingança, mas de amor, de humanidade". ${ }^{37}$ Para tanto, argumenta Vicente, é necessário recorrer à música, ao canto, ao teatro, enfim, a todas as artes. Por meio da arte é possível sensibilizar, despertar emoções e sentimentos positivos.

Tais sentimentos também podem ser provocados, de acordo com Telles, por meio da História: "Se a História não serve para despertar sentimento de humanitarismo, não serve

\footnotetext{
36 Idem

37 Entrevista gravada na casa de Vicente Telles/Julho de 2006.
} 
para conscientizar, então não serve para nada. É apenas uma tortura mental, para responder questões de provas ou vestibular".38 Desse modo, defende uma História encenada, dramatizada, "viva", que fuja "às palestras eruditas, realizadas em ambientes enfeitados, cheios de flores, com tapetes de veludo, que o povo nunca teve acesso. Teve acesso ali apenas os intelectuais, os que escrevem livros, os que defendem teses". 39

A importância que Vicente vem conferindo, ao longo de décadas, às artes e à história "viva" perpassa todo seu trabalho: das ideias e imagens criadas, acerca do Contestado, às linguagens ou veículos escolhidos para representá-las, fundamentando o que, até então, vem sendo um dos grandes registros de sua produção, o CD Epopeia do Contestado - História em Música. Viabilizado em 2001, pela lei de Incentivo à Cultura do Estado de Santa Catarina, e, apresentado ao público como um produto cultural de cunho pedagógico, o CD tem a intenção de conscientizar sobre o que foi o Contestado e, ao mesmo tempo, contribuir para a valorização da identidade catarinense. Sobre a dupla finalidade do mesmo, aponta Vicente:

Daí a necessidade de mostrar a todo o Estado de Santa Catarina o trabalho de resgate do 'Espírito do Contestado'. Desta forma, estaremos pacificando sua história, arrefecendo quaisquer resistências, criando um sentimento forte, claro, simples e objetivo para as novas gerações. Somente assim faremos brotar um 'Catarinismo' próprio e exclusivo da terra dos catarinenses, que, por certo, irá enriquecer os eventos étnicos já existentes no Estado. ${ }^{40}$

Como podemos perceber, para o autor, pacificar o Contestado é resgatar seu próprio espírito a fim de torná-lo público. Condição esta, fundamental para que nasça uma identidade entre as novas gerações, seus antepassados - caboclos ou imigrantes europeus - e a terra a que pertencem. O "catarinismo", exemplo de "civismo local", seria a expressão maior dessa identidade.

\footnotetext{
38 Idem

${ }^{39}$ Idem

40 Idem
} 


\section{IRANI: REDUTO DAS REPRESENTAÇÕES}

0 envolvimento de parte da população nos eventos realizados pelo folclorista, bem como, a influência que por vezes Telles parece ter exercido sobre os materiais de divulgação do Contestado, elaborados pelo poder municipal, encontra explicação nas próprias condições sócio-econômicas de Irani.

Localizado no Meio-Oeste catarinense, o município tem como principais fontes de sustento as atividades agropecuárias que dificilmente ampliam a visibilidade de Irani em termos estaduais. Para tal fim, uma das possibilidades seria o desenvolvimento do setor terciário, a partir do incremento do comércio e da prestação de serviços, favorecidos pela exploração do turismo local. Nos últimos anos, o turismo vem recebendo incentivos por parte das autoridades e instituições municipais e estaduais. Neste setor, são enfatizados referenciais geográficos, ambientais e históricos encontrados em Irani.

A Prefeitura Municipal de Irani e a Fundação Cultural Memória Viva do Contestado, presidida por Vicente Telles, até hoje somam esforços para tentar consolidar a visão de que a guerra originou-se a partir do Combate do Irani, como já vimos anteriormente. A imagem do município enquanto berço do Contestado busca sua legitimidade nos próprios componentes que predominam como atrativos diferenciados oferecidos pelo turismo local. Tais componentes, isto é, monumentos, marcos ou referências alusivos ao Contestado integrariam o projeto do futuro Parque Temático do Contestado.

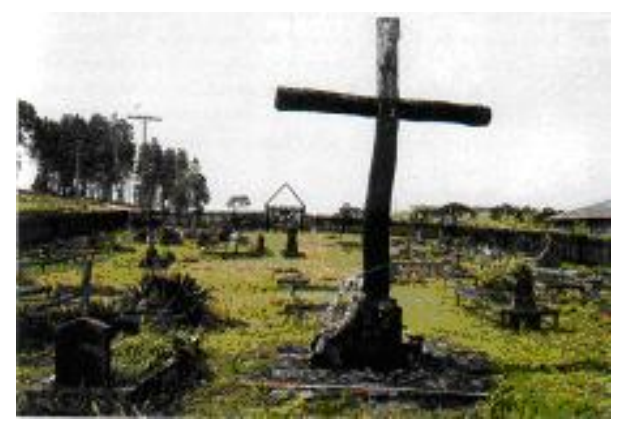

Cemitério do Contestado Revista Mares do Sul. Foto de Iolita Cunha, dezembro de 1998 e janeiro 1999.

Cenários repletos de paisagens naturais também são apresentados como elementos atrelados a episódios do tempo da guerra, como o Vale da Morte, cuja denominação homenageia os mortos na Batalha do Irani. Outro exemplo, bastante significativo, é a Gruta 
Pigosso, localizada a $6 \mathrm{~km}$ do centro da cidade, utilizada, na época, pelos sertanejos que fugiam das tropas militares durante a guerra. Permanências da cultura cabocla são motivo de orgulho para os idealizadores do projeto turístico. Resquícios das tradições culturais dos antigos sertanejos ainda são preservados por meio da gastronomia local, onde dois dos restaurantes existentes em Irani oferecem receitas da culinária cabocla. Pratos típicos também são vendidos em jantares anuais, durante as comemorações da Semana do Contestado, realizada em outubro.

Entretanto, nem só interesses e necessidades especificamente econômicas justificam a reconstrução da memória do Contestado. As representações "individuais", do nosso autor transformam-se em representações sociais, isto é, coletivas também no âmbito da cultura. Como exemplo, citamos uma Escola Municipal, recém inaugurada, cujas salas de aula, como nos foi informado pela diretora, receberiam futuramente nomes dos principais "heróis" da guerra: José Maria, Chica Pelega, Maria Rosa, Matos Costa, Adeodato, entre outros. Na cidade também fomos informados de um novo espetáculo, realizado por integrantes do grupo local Malhadança e patrocinado pela Prefeitura Municipal de Irani, intitulado Heróis do Contestado, o qual, ao que tudo indica, parece ter buscado "inspiração" diretamente nas ideias de Telles, mantendo a mesma estrutura de montagem e criação - canto, música, dramatização e dança e as mesmas concepções do autor. Indícios de que as representações de Telles encontram acolhimento na cidade.

\section{CONSIDERAÇÕES FINAIS}

\footnotetext{
0 passado traz consigo um índice misterioso, que o impele à redenção. Pois não somos tocados por um sopro do ar que foi respirado antes? Não existem nas vozes que escutamos, ecos das vozes que emudeceram? Não têm as mulheres que cortejamos irmãs que elas não chegaram a conhecer? Se assim é, existe um encontro secreto, marcado entre as gerações precedentes e a nossa. Alguém na terra está a nossa espera. Nesse caso, como a cada geração, foi-nos concedida uma frágil força messiânica para a qual o passado dirige um apelo. Esse apelo não pode ser rejeitado impunemente. (Walter Benjamin. Sobre o conceito da historia. Tese II)
}

Ao "recriar" a memória do Contestado em Irani, Vicente Telles redimensionou sua própria vida. Relativamente jovem e aposentado, descobriu na guerra e no movimento uma maneira de "reencantar seu mundo". Encontrando na arte e na "história viva" os veículos para a redenção e divulgação do Contestado, Telles, acreditando-se herdeiro direto da saga cabocla, 
assumiu o papel de redentor dos sujeitos históricos, que como ele mesmo afirma, lutaram e morreram em defesa da terra, atualmente dividida e desfrutada por um maior número de catarinenses.

A proposta de redenção passa, portanto, pela popularização do que foi, do que é, e do que poderá ser o Contestado, por meio da arte e da história. Daí o caráter pedagógico assumido pela obra de Vicente, promotor do "diálogo", isto é, do "encontro" entre três tempos: passado, presente e futuro. Sintetizado pela frase "Contestado é a voz do passado, falando ao presente, alertando ao futuro", tal "diálogo" sustenta vários desdobramentos das imagens criadas por Vicente. Da herança que os sertanejos desalojados deixaram aos integrantes do Movimento dos Sem-Terra; passando pela permanência do problema social da má distribuição fundiária, que corre o risco de se perpetuar no futuro; até chegar a necessidade de se construir uma identidade catarinense, baseada nas noções de civismo, amor à terra e à natureza, legadas pelos caboclos às gerações atuais.

Do ponto de vista do regional para o local, encontramos na questão da identidade do catarinense atual talvez o maior "elo" de ligação entre as representações de Vicente e as imagens criadas por Amin. "Elo", capaz de explicar os vínculos, os apoios e as considerações mútuas existentes entre o Governo Estadual e a Fundação Cultural Memória Viva do Contestado de Irani, durante os dois mandatos do ex-governador.

Partindo do pressuposto de que toda construção ou reconstrução de uma memória do passado vem de encontro a objetivos, interesses e necessidades do presente, e de que as representações, que compõem um certo imaginário, não são discursos neutros, mas que estão imbuídas de interesses específicos, acreditamos que o "resgate" do Contestado em Irani atende a uma expectativa comum por parte da Fundação Cultural Memória Viva do Contestado, Prefeitura Municipal e de parte da comunidade urbana do município: a de projetar Irani no cenário estadual como referência maior do turismo histórico cultural, voltado à temática do Contestado. Em outras palavras, a exaltação do combate, a idealização dos caboclos, a mitificação de José Maria, a definição de uma identidade por meio do catecismo cívico, a preservação e construção de monumentos e a realização de eventos, como os desfiles e quadros cênicos, com atores e figurantes devidamente alegorizados, ultrapassam imagens e representações mais individuais transformando-se em coletivas quando o assunto aponta para uma perspectiva de desenvolvimento e projeção do município. 
A idealização dos caboclos iniciada por Vicente, com o predomínio de cenas de heroísmo, ousadia, bravura e pureza, está presente nas fotografias das encenações realizadas nos desfiles e quadros cênicos, as quais envolveram centenas de moradores ao longo dos anos. A preferência pelo terceiro monge, o monge guerreiro e mártir encontra também respaldo no solo atual de Irani. As imagens delineadas no CD Epopéia do Contestado - História em Música e nas entrevistas concedidas por Vicente Telles, que ressaltam a figura de José Maria, não se construíram num vazio social. Antes foram formadas tendo em vista ideais e interesses complementares e possuem uma dupla aspiração: a de legitimar o episódio ocorrido no Banhado Grande enquanto marco inicial de periodização da guerra, e, com isso promover a importância do município, no cenário estadual, sobrepondo Irani aos demais, enquanto primeira referência do turismo histórico cultural.

\section{REFERÊNCIAS}

AMIN, Esperidião. Cadernos da Cultura Catarinense. In: TELLES, Vicente (org). Folclore Itinerante da Epopeia do Contestado: história em música. (Encarte do CD Epopeia do Contestado - História em Música). Irani: [s.n.], 2002.

AURAS, Marli. Guerra do Contestado: a organização da Irmandade cabocla. 2. ed. Florianópolis: UFSC, 1995.

ÁVILA, Clari de; et al. Irani: um pedaço do paraíso. Irani: Blumen, [199_?].

BORELLI, Romário. O Estado do Paraná, 05.10.1979. In: VALENTINI, Delmir José. Da Cidade Santa à Corte Celeste: memórias de sertanejos e a Guerra do Contestado. Santa Catarina: Universidade do Contestado, 2003.

CABRAL, Oswaldo Rodrigues. A Campanha do Contestado. Florianópolis: Lunardelli, 1979.

CARVALHO, José Murilo. Mandonismo, coronelismo e clientelismo: uma discussão conceitual. Revista de Ciências Sociais, Rio de Janeiro, v. 40, n. 2, 1997.

o Rio de Janeiro e a República que não foi. São Paulo: Companhia das Letras, 1990. 
CHARTIER, Roger. A História Cultural: entre práticas e representações. Rio de Janeiro: Bertrand Brasil, 1990. (Memória e Sociedade)

CONTESTADO. 4. ed. Florianópolis: IOESC (Imprensa Oficial do Estado de Santa Catarina), 2001.

FACHEL, José Fraga. Monge João Maria: recusa dos excluídos. Florianópolis: UFSC, 1995.

FELIPPE, Euclides J. O Último Jagunço: folclore na História do Contestado. Curitibanos: Universidade do Contestado, 1995.

GALLO, Ivone Cecilia D’Ávila. O Contestado: o sonho do milênio igualitário. São Paulo: Unicamp, 1999.

OLIVEIRA, Susan Aparecida de. Guerra do Contestado: mímesis e políticas de memória. Florianópolis: UFSC, 2006.

MACHADO, Paulo Pinheiro. Lideranças do Contestado: a formação e a atuação das chefias caboclas (1912-1916). Campinas: Unicamp, 2004.

MONTEIRO, Duglas Teixeira. Os Errantes do Novo Século: um estudo sobre o surto milenarista do Contestado. São Paulo: Duas Cidades, 1974.

Um confronto entre Juazeiro, Canudos e Contestado. In: PINHEIRO, Paulo Sérgio. O Brasil Republicano: sociedades e instituições (1889-1930). Rio de Janeiro: Bertrand Brasil, 2004.

NANCY, Jean-Luc e LACQUE-LABARTHE, Philippe. O mito nazista. Trad. Márcio Seligmann Silva. São Paulo: Iluminuras, 2002, pp. 32-33.

NETO, Godofredo de Oliveira. O bruxo do Contestado. Rio de Janeiro: Nova Fronteira, 1996.

REVISTA Nossa História. Fé e Luta: movimentos messiânicos que incendiaram o Brasil. Rio de Janeiro, Ano 3, n. 30, abr. 2006.

SALOMÃO, Eduardo Rizatti. Interpretações sobre a Guerra Sertaneja do Contestado (1912-1916): o fundo material e o messianismo. Revista do Instituto de Ensino, Pesquisa e Prestação de Serviços IEPS, União da Vitória, v. 1, n. 1, dez./jun. 2002. 
SCHÜLER, Donald. Império Caboclo. Florianópolis: UFSC, 2004.

TESSER, Rosa Maria. O Contestado: a história que o Brasil não conhece. Florianópolis: Ed. da Autora, 2005.

THOMÉ, Nilson. Breve História do Contestado. Caçador (SC): UnC Campus Caçador, 2005.

Uma nova História para o Contestado. Santa Catarina: Universidade do Contestado/Museu do Contestado, 2004. (Coleção Memória do Contestado)

Os Iluminados: personagens e manifestações místicas e messiânicas no Contestado. Florianópolis: Insular, 1999.

. VALE AMADO, Davi J. F. do. Contestado: pelados versus peludos - Uma batalha ainda não vencida. São Paulo: Fundação Biblioteca Nacional / Ministério da Cultura, 2002.

VALENTINI, Delmir José. Da Cidade Santa à Corte Celeste: memórias de sertanejos e a Guerra do Contestado. Santa Catarina: Universidade do Contestado, 2003.

VASCONCELLOS, A. Sanford de. Chica Pelega: a guerreira de Taquaruçu. Florianópolis: Insular, 2000.

. O dragão vermelho do Contestado. Florianópolis: Insular, 1998.

WAGNER, Wolfgang. Sócio-Gênese e Características das Representações Sociais. In: MOREIRA, Antonia Silva Paredes; OLIVEIRA, Denise Cristina de (ORG). Estudos Interdisciplinares de Representação Social. Goiânia: AB, 1998.

WEINHARDT, Marilene. Mesmos crimes, outros discursos? Curitiba. Ed. da UFPR, 2000.

WOITOWICZ, Karina Janz. Imagem Contestada: A Guerra do Contestado pela escrita do Diário da Tarde (1912-1916). Ponta Grossa. Editora UEPG, 2014. 